\title{
Microbiological Quality of Goat Carcasses at Different Stages of Slaughter in Dallam Island Abattoir
}

\author{
Hamdan Mustafa Hamdan ${ }^{1}$, Mohamed Ismail Mohamed Fangama ${ }^{2}$, \\ Siham Elias Suliman ${ }^{1}$, Ismail Mohamed Fangama ${ }^{3}$ and \\ Mohammed Abdel Salam Abdalla ${ }^{1}$ \\ ${ }^{1}$ College of Veterinary Medicine (SUST) \\ ${ }^{2}$ Ministry of Health, Qatar Public Health Department \\ ${ }^{3}$ College of Forestry and Range Science (SUST)
}

\section{Keywords \\ Goat carcasses, Slaughter, E. coli Staphylococcus aureus}

Article Info

Accepted:

04 February 2019

Available Online:

10 March 2019

\section{A B S T R A C T}

A study was carried out to evaluate the microbial quality of goat carcasses at Dallma island slaughterhouse in Alzafraa District, UAE, during June 2017. A total of 284 swab samples were collected from 40 carcasses for identification of the isolates and bacterial total viable counts (TVCs). Cotton swab samples were also collected from knives and hands of workers used in the slaughter process. The study found that predominant bacterial isolates at Dallma were E.coli and Staphylococcus aureus and these were revealed very low values before and after treatment of operational points also at worker's hands and their knives were low, but Salmonella spp. was not detected. The mean total viable count (TVCs) post skinning, post evisceration and post washing at neck site was $2.26 \pm 0.81,2.48 \pm 0.81$ and $2.74 \pm 0.66 \mathrm{log} \mathrm{CFU} / \mathrm{cm}^{2}$ before the treatment, whereas after treatment was $1.60 \pm 0.60,1.65 \pm 0.58$ and $1.33 \pm 0.58 \mathrm{log} \mathrm{CFU} / \mathrm{cm}^{2}$ with statistically significant difference $(\mathrm{P}<0.05)$. In brisket site, TVCs before treatment of the carcasses were $2.24 \pm$ $0.64,2.62 \pm 0.57$ and $3.01 \pm 0.52 \log _{10} \mathrm{CFU} / \mathrm{cm}^{2}$ but after the treatment of the samples were $1.67 \pm$ $0.94,1.87 \pm 0.74$ and $1.68 \pm 0.81 \mathrm{CFU} / \mathrm{cm}^{2}$, with statistically significant difference $(\mathrm{P}<0.05)$. TVCs of the samples from the rump site samples before treatment at operational points, revealed mean $2.54 \pm$ $0.49,2.56 \pm 0.84$ and $2.37 \pm 0.63 \log _{10} \mathrm{CFU} / \mathrm{cm}^{2}$ and after treatment were, $1.73 \pm 0.81,1.87 \pm 0.74$ and $1.55 \pm 0.62 \log _{10} \mathrm{CFU} / \mathrm{cm}^{2}$ respectively $(\mathrm{P}<0.05)$. In shoulder site, TVC in the three points of operation before treatment were $1.37 \pm 0.62,2.75 \pm 0.84$ and $2.73 \pm 0.66 \log _{10} \mathrm{CFU} / \mathrm{cm}^{2}$, whereas after treatment $1.40 \pm 0.73,1.73 \pm 0.45$ and $1.61 \pm 0.69 \log _{10} \mathrm{CFU} / \mathrm{cm}^{2}$ with statistically significant. TVC in knives after skinning and evisceration before treatment samples were $3.23 \pm 0.66$ and $3.00 \pm 0.48 \log$ $\mathrm{CFU} / \mathrm{cm}^{2}$ while after treatment were $1.18 \pm 0.28$ and $1.30 \pm 0.47 \log \mathrm{CFU} / \mathrm{cm}^{2}$. Also the TVC, of the hands of the workers post skinning, post evisceration and post washing were $3.15 \pm 0.37,3.43 \pm 0.34$ and 3.15 $\pm 0.30 \log _{10} \mathrm{CFU} / \mathrm{cm}$ before treatment samples, but in treated samples were $2.54 \pm 0.41,1.64$ \pm 0.44 and $2.68 \pm 0.79 \log _{10} \mathrm{CFU} / \mathrm{cm}^{2}$ respectively. The decontamination processes are important to eliminate the sources of contamination and that by application of food safety methods such as HACCP and an appropriate training for personnel.

\section{Introduction}

Gulf States are a major small ruminant's importer of meat. It represents the world's largest import market for live sheep and goats to meet the strong consumer demand, as sheep and goat meat forms an important component of the Arab diet (Cernicchiaro, 2013). Goat meat, and especially kid meat, is increasingly being consumed for its characteristic taste, 
desired chemical composition and nutritional properties. Like all other types of meat, goat meat can also be a source of pathogenic bacteria. Bacteria can reach the surface of the carcasses during slaughtering of healthy goats and carcass processing. The operations of skinning and evisceration are highly risky for carcass contamination by microorganisms (Ivanovic et al., 2011; Ivanovic et al., 2014). Meat, a rich source of the protein and fat, low in carbohydrate content and with sufficient water activity, supports the growth of both spoilage and pathogenic bacteria. Growth of yeasts and molds is essentially slow on fresh meat as compared with bacteria; therefore, they are not major component of spoilage flora (Doyle, 2007). The food and Agricultural organization (FAO) of the United Nations and the World Health Organization (WHO) stated that illness due to contaminated food is perhaps the most widespread health problem and an important cause of reduced economic productivity (Käferstein, 2003). Raw meat may harbor many important pathogenic microbes i.e. Salmonella spp., Campylobacter jejuni/coli, Yersinia enterocolitica, E. coli, S. aureus and, to some extent, Listeria spp., making the meat as risk for human health, without the proper handling and control of these pathogens, food borne ill-nesses may occur (Nørrung et al., 2009). Meat, an excellent source of protein in human diet is highly susceptible to microbial contaminations, which can cause its spoilage and food borne infections in human, resulting in economic and health losses (Komba et al., 2012). Although muscles of healthy animals do not contain microorganisms, meat tissues get contamination during the various stages of slaughter and transportation (Ercolini et al., 2006). A great diversity of microbes inhabit fresh meat generally, but different types may become dominant depending on $\mathrm{pH}$, composition, textures, storage temperature, and transportation means raw meat (Ercolini et al., 2006; Li et al., 2006; Adu- Gyamfi et al.,
2012). Microbial contamination of animal carcasses during slaughtering is an unavoidable problem in the conversion of live animals to meat for consumption (Dickson and Anderson, 1991). The contamination of meat by microbial pathogens can occur at any stage of the meat chain (Duffy et al., 2006; Rhoades et al, 2009). Furthermore, the prevention or mastery of meat contaminations can be carried out at a stage of the chain different from the stages at which the contamination has occurred (Chen et al., 2012). Carcass dressing and evisceration processes constitute critical points in the microbial contamination of muscle for which corrective measures need to be implemented (Bacon et al., 2000; Abdalla et al., 2009a; Abdalla et al., 2009b). Cattle slaughter operations, such as bleeding, dressing, and evisceration, may expose sterile muscle to microbiological contaminants that are present on the skin, the digestive tract, and in the environment (Gill and Jones, 1999; Bacon et at., 2000; Abdalla et al., 2009a; Abdalla et at., 2009b). It has been demonstrated that the workers and their slaughter instruments could spread contamination into the internal organs of beef cattle. Dickson and Anderson (1992) isolated Salmonella spp. and Escherichia coli from the hands of workers. The presence of bacteria of potential public health significance was explained by Dolye (2007) and Biss and Hathaway (1995) during slaughtering operations. There were significance increases in total bacterial counts at skinning points than that at washing operations and also dirty worker's' hands, clothes and equipments of the slaughterhouse acted as intermediate sources of contamination of meat (Gill,1998; Gilmour et aI., 2004; Abdelsadig, 2006; Abdalla et al., 2009a; Abdalla et al., 2009b). Ali (2007) recorded high contamination level on rump sites during skinning. Cattle and their environment were represented important sources of pathogenic E. coli (Hancock et al., 1998; Elder et al., 2000). The aim of this study 
was to determine the microbiological contamination of goat carcasses processed on a slaughter line in a slaughterhouse, by determining the TVC, number and the presence of Enterobacteriaceae and then categorizing the bacterial levels.

\section{Materials and Methods}

\section{Sample collection}

A total number of 284 swabs from 40 goat carcasses were collected from the neck, rump, shoulder and brisket during operational points; skinning, evisceration and washing at Dallma island slaughterhouse in Alzafraa District, UAE. Muscle carcass sites were sampled by swab technique (Bell, 1997).

An area of $100 \mathrm{~cm}^{2}$ marked with a sterile frame of $10 \mathrm{~cm} \times 10 \mathrm{~cm}$ on each site of the carcass was rubbed for 30 seconds and swabs were transferred to a screw-capped test tube containing $10 \mathrm{ml}$ of sterile maintenance medium $(0.85 \% \mathrm{NaCl}$ and $0.1 \%$ peptone). Also 60 samples from worker hands and 60 samples from their knives. These samples were taken at different operation points of slaughtering process. The tubes were transported to microbiology laboratory at $4{ }^{\circ} \mathrm{C}$ for further analysis within 4 hours.

\section{Aerobic plate count (APC)}

Aerobic plate count was carried out on total plate count agar as described by Bell (1997). The medium was autoclaved and maintained at $46^{\circ} \mathrm{C}$. Samples were serially diluted and an aliquot of $1 \mathrm{ml}$ of each of serial dilution was transferred to the petri dishes (4 inch diameter) and molten agar (15-20 ml) was poured on it. Plates were gently swirled to uniformly mix the sample and incubated at $37^{\circ} \mathrm{C}$ for 48 hours. After incubation APC was determined from appropriate plates.

\section{Enumeration of Escherichia coli}

Escherichia coli were enumerated on Eosin methylene blue agar (Oxoid, 2006) by plating an appropriate dilution on plates followed by aerobic incubation at $37^{\circ} \mathrm{C}$ for $24 \mathrm{hrs}$. After incubation $E$. coli were counted as colonies with distinct metallic sheen (Bhandare et al., 2007).

\section{Isolation and identification of Staphylococcus aureus}

The bacteriological culture was performed following the standard microbiological technique (Quinn et al., 2002). Swab samples were streaked on blood agar media using cotton applicator and the plates were incubated aerobically at $37^{\circ} \mathrm{C}$ and examined after $24-48 \mathrm{~h}$ of incubation. The colonies were identified based on morphological characteristics, hemolytic pattern and Gram's staining reaction. The representative colonies which were positive for Gram's staining and typical grapes like structure under microscope were further sub-cultured on nutrient agar plates (Oxoid, 2006) and incubated at $37{ }^{\circ} \mathrm{C}$ for 24 hours. Pure colonies were preserved and maintained on nutrient slants for further characterization of the isolates. Eventually, identification of the agent was done based on biochemical tests and these were catalase, coagulase, mannitol salt agar and purple agar base tests. Samples were considered positive for Staph. aureus when the isolates were catalase and coagulase positive and showed fermentation of mannitol and maltose (Strong yellow discoloration of both media).

\section{Salmonella detection}

Samples were subjected to Salmonella detection according to ISO 6975 (ISO, 2002), with some modifications. Under sterile conditions, each sample set was treated with $160 \mathrm{~mL}$ of BPS (Oxoid, 2006) and 
homogenised at $4{ }^{\circ} \mathrm{C}$ and $260 \mathrm{rpm}$ (Stomacher 400 circulator, Seward, Worthing, England). Then, $40 \mathrm{~mL}$ of the obtained homogenates were centrifuged at $1000 \times g$ for $15 \mathrm{~min}$, the supernatant was discarded, and the obtained pellet was re-suspended in $10 \mathrm{~mL}$ of buffered peptone water at $1 \%(\mathrm{w} / \mathrm{v})$; this was followed by incubation at $37{ }^{\circ} \mathrm{C}$ for $18 \mathrm{~h}$. Then, the obtained cultures were transferred to MullerKauffmann tetrathionate/ novobiocin broth and Rappaport-Vassiliadis medium with soya, which were incubated at $37{ }^{\circ} \mathrm{C}$ - for $42{ }^{\circ} \mathrm{C} 24$ hours, respectively. The obtained cultures were streaked onto plates containing xylose lysine deoxycholate agar and mannitol lysine crystal violet brilliant green agar and incubated at $37{ }^{\circ} \mathrm{C}$ for 24 hours. Salmonella suspect colonies were transferred to triple sugar iron agar and lysine iron agar slants and incubated at $37^{\circ} \mathrm{C}$ for 24 hours (Oxoid, 2006).

\section{Statistical analysis}

All bacterial counts were converted to $\log _{10}$ $\left(\mathrm{cfu} / \mathrm{cm}^{-2}\right)$ for analysis. ANOVA was performed. Statistical significance was set at P- value of $\leq 0.5$.

\section{Results and Discussion}

The mean total viable count (TVCs) post skinning, post evisceration and post washing at neck site was $2.26 \pm 0.81,2.48 \pm 0.81$ and $2.74 \pm 0.66 \log \mathrm{CFU} / \mathrm{cm}^{2}$ before the treatment, whereas after treatment was $1.60 \pm 0.60,1.65$ \pm 0.58 and $1.33 \pm 0.58 \log \mathrm{CFU} / \mathrm{cm}^{2}$ with statistically significant difference $(\mathrm{P}<0.05)$. In brisket site, TVCs before treatment of the carcasses were $2.24 \pm 0.64,2.62 \pm 0.57$ and $3.01 \pm 0.52 \log _{10} \mathrm{CFU} / \mathrm{cm}^{2}$ but after the treatment of the samples were $1.67 \pm 0.94$, $1.87 \pm 0.74$ and $1.68 \pm 0.81 \mathrm{CFU} / \mathrm{cm}^{2}$, with statistically significant difference $(\mathrm{P}<0.05)$. TVCs of the samples from the rump site samples before treatment at operational points, revealed mean $2.54 \pm 0.49,2.56 \pm 0.84$ and
$2.37 \pm 0.63 \log _{10} \mathrm{CFU} / \mathrm{cm}^{2}$ and after treatment were, $1.73 \pm 0.81,1.87 \pm 0.74$ and $1.55 \pm 0.62$ $\log _{10} \quad \mathrm{CFU} / \mathrm{cm}^{2}$ respectively $(\mathrm{P}<0.05)$. In shoulder site, TVC in the three points of operation before treatment were $1.37 \pm 0.62$, $2.75 \pm 0.84$ and $2.73 \pm 0.66 \log _{10} \mathrm{CFU} / \mathrm{cm}^{2}$, whereas after treatment $1.40 \pm 0.73,1.73$ \pm 0.45 and $1.61 \pm 0.69 \quad \log _{10} \mathrm{CFU} / \mathrm{cm}^{2}$ with statistically significant difference (Table 1).

TVC in knives after skinning and evisceration before treatment samples were $3.23 \pm 0.66$ and $3.00 \pm 0.48 \log _{10} \mathrm{CFU} / \mathrm{cm}^{2}$ while after treatment were $1.18 \pm 0.28$ and $1.30 \pm 0.47 \quad \log _{10}$ $\mathrm{CFU} / \mathrm{cm}^{2}$ (Table 2). Also the TVC, of the hands of the workers post skinning, post evisceration and post washing were $3.15 \pm 0.37$, $3.43 \pm 0.34$ and $3.15 \pm 0.30 \log _{10} \mathrm{CFU} / \mathrm{cm}$ before treatment samples, but in treated samples were $2.54 \pm 0.41,1.64 \pm 0.44$ and $2.68 \pm 0.79 \log _{10}$ $\mathrm{CFU} / \mathrm{cm}^{2}$ respectively (Table 2 ).

Isolation and identification of bacteria at different operational points under investigation showed that Salmonella spp. was not detected, but $E$. coli was detected in very (low $<3$ CFU/swab) and Staphylococcus aureus ( $<10 \mathrm{CFU} / \mathrm{swab})$ revealed very low values before and after treatment of operational points also at worker's hands and their knives were low.

The acceptable international standards for swab values which are $<2.8 \mathrm{log} \mathrm{CFU} / \mathrm{cm}^{2}$ for TVC, and the unacceptable values are $>4.3 \mathrm{log}$ $\mathrm{CFU} / \mathrm{cm}^{2}$, respectively were set and agreed to be a criterion for assessing and evaluating the microbial contamination of carcasses and a useful mean to know the hygienic and safety states of meat. According to the Decision 2001/471/EC of the EU Commission, the acceptable value of TVC was set at $2.8 \log 10$ $\mathrm{cfu} / \mathrm{cm}^{2}$ (EU, 2001). The present results recorded that the bacterial counts (Table 1) were high in the four sites (neck, shoulder, brisket and rump) before treatment at 
skinning, evisceration and washing. These findings in agreement with the findings of Gill and Barker (1998) and Abdalla et al., (2009a) who reported that meat contaminated by bacteria during skinning operation. The contamination of meat at different parts showed significant statistical difference in the microbial count (Mboto et al., 2012). The reduction of TVC after treatment in this study may be attributed to proper wearing and cleaning of the body before and after skinning resulting in the decreased level of contaminating bacteria (Aftab et al., 2012).

Also evisceration process has an important role in contamination of the muscles, because the feces are riched with coliform bacteria (Collobert et al., 2002; El-Hadef et al., 2005; Bhandare et al., 2007). Washing of the body reduced the level of organisms with complete wearing of protective clothes as shown in our study, whereas in another study of Ali (2007) and Abdalla et al., (2009b) recorded that post washing might increase the level.

In this study the bacterial count from workers' hands after treatment showed significant reduction (Table 2) compared with control and the washing of knives by warm water $\left(82{ }^{\circ} \mathrm{C}\right)$ decreased the level of viable bacteria. These results are similar to the results of Abdalla et al., (2010). The presence of bacteria in meat in the slaughterhouse indicated that unhygienic handling of meat. The decontamination processes are important to eliminate the sources of contamination and that by practicing an appropriate training for personnel, application of good hygienic methods.

The contamination of $E$. coli occurs in meat through soiling of the carcass and plant environment with faecal materials during slaughter process. This contamination is mainly evident where slaughter procedures are not hygienic. The results in the current agree with Jeffery et al., (2013) in bovine carcasses in Sudan whereby E. coli represented the highest average prevalence. Sudan and Malawi are tropical countries, with ambient temperatures conducive for the growth of microorganisms resulting in rendering meat unsafe for human consumption. They can be found in the air, dust, water and human faeces, and can be present on clothing and utensils handled by human.

Staphylococci are a normal part of the microflora of the nose throat and skin and only $S$. aureus is considered to be pathogenic (Clarence et al., 2009) and the nasal passage is the most significant site. For instance Abdalla et al., (2009) found $3.74 \pm 0.02$ $\log 10 \mathrm{CFU} / \mathrm{cm}^{2}$ on hands of workers in Sudan before skinning in sheep which is lower than $3.01 \pm 0.52 \log _{10} \mathrm{CFU} / \mathrm{cm}^{2}$ at brisket before treatment at washing point. In their study, they also found lower TVC of $3.40 \pm 0.02 \log _{10}$ $\mathrm{CFU} / \mathrm{cm}^{2}$ on knives against $6.38 \pm 0.38 \log _{10}$ $\mathrm{CFU} / \mathrm{cm}^{2}$ in this study. Another study by Jeffery et al., (2013) revealed that the workers' hands and the equipment were the sources of meat contamination and these results are in accordance with the present results.

However, the TVC for knives before treatment is much lower than what was reported by Adetunji and Odetokun (2011) who found $14.01 \log _{10} \mathrm{CFU} / \mathrm{cm}^{2}$ in tropical goat abattoir in Nigeria. In this study the findings obtained suggest that the hygienic procedures conducted during slaughtering process were enough to avoid the contamination by Salmonella spp. in the processing environment. 
Table.1 Mean \pm Sd of Total viable counts $\left(\operatorname{Iog} 10 \mathrm{cfu} \mathrm{cm}^{2}\right)$ on sites of the carcasses in goats $(n=284)$ in Dellma Island slaughterhouse, at Abudaibi, UAE

\begin{tabular}{|c|c|c|c|c|c|c|c|}
\hline \multirow[t]{3}{*}{ Site } & \multicolumn{6}{|c|}{ Operational points } & \multirow[t]{2}{*}{ Sig. } \\
\hline & \multicolumn{3}{|c|}{ Before treatment } & \multicolumn{3}{|c|}{ After treatment } & \\
\hline & Skinning & Evisceration & Washing & Skinning & Evisceration & Washing & \\
\hline Neck & $2.26 \pm 0.81$ & $2.48 \pm 0.81$ & $2.74 \pm 0.66$ & $1.63 \pm 0.60$ & $1.65 \pm 0.58$ & $1.33 \pm 0.58$ & $*$ \\
\hline Brisket & $2.24 \pm 0.64$ & $2.62 \pm 0.57$ & $3.01 \pm 0.52$ & $1.67 \pm 0.94$ & $1.87 \pm 0.74$ & $1.68 \pm 0.81$ & $*$ \\
\hline Rump & $2.54 \pm 0.49$ & $2.56 \pm 0.84$ & $2.37 \pm 0.63$ & $1.73 \pm 0.81$ & $1.87 \pm 0.74$ & $1.55 \pm 0.62$ & $*$ \\
\hline Shoulder & $1.37 \pm 0.62$ & $2.75 \pm 0.84$ & $2.73 \pm 0.66$ & $1.40 \pm 0.73$ & $1.73 \pm 0.45$ & $1.61 \pm 0.69$ & $*$ \\
\hline
\end{tabular}

$*=($ Sig. $)$ significant at level $(\mathrm{P}<0.05)$

Table. 2 Mean \pm Sd of Total viable counts of bacteria $\left(\log 10 \mathrm{cfu} / \mathrm{cm}^{2}\right)$ at hands of the workers and knives before treatment and after treatment on different sites of the goats $(n=284)$ carcasses in Dellma Island slaughterhouse at Abudaibi, UAE

\begin{tabular}{|l|l|l|l|l|l|l|}
\hline \multirow{2}{*}{ Site } & \multicolumn{5}{|c|}{ Operational points } \\
\cline { 2 - 7 } & \multicolumn{5}{|c|}{ Before } & \multicolumn{3}{c|}{ After } \\
\cline { 2 - 7 } & Skinning & Evisceration & Washing & Skinning & Evisceration & Washing \\
\hline Hands & $3.15 \pm 0.37 *$ & $3.43 \pm 0.34^{*}$ & $\begin{array}{l}3.15 \pm 0.37 \\
*\end{array}$ & $2.54 \pm 0.41^{*}$ & $1.64 \pm 0.44^{*}$ & $2.68 \pm 0.79 *$ \\
\hline Knives & $3.23 \pm 0.66^{*}$ & $3.00 \pm 0.48^{*}$ & ND & $1.18 \pm 0.28^{*}$ & $1.30 \pm 0.47^{*}$ & ND \\
\hline
\end{tabular}

$*=$ significant at level $(\mathrm{P}<0.05), \mathrm{ND}=$ not detected

The low occurrence of Salmonella spp. in bovine carcasses during slaughtering has already been observed in similar studies conducted in other countries (Li et al., 2004; Rhoades et al., 2009). Also, the contamination of bovine carcasses after the end of the slaughtering process (after the end washing) could be a relevant source of the initial contamination of Salmonella spp. in the beef processing environment of slaughterhouses (Ruby et al., 2007). In conclusion, this study showed that the level of contamination on goat carcasses was higher than the acceptable value set by the EU. However, to attain the international requirements and acceptable value set by the EU (2001) Commission, involving good sanitary measures during slaughtering processes that will lead to the reduction of the amount of the microorganisms and other hazards should be stressed on. Hazard Analysis Critical Control Point (HACCP) should be applied properly during slaughtering operations. To make all these, extensive education and training programs on hygiene for workers should immediately be started.

\section{References}

Abdalla MA, Suliman SE, Ahmed DE, Bakhiet AO.(2009). Estimation of bacterial contamination of indigenous bovine carcasses in Khartoum (Sudan). Afr J Microbiol Res. 3:882-6.

Abdalla, M.A., Siham, E. Suliman and Alian, Y. Y.H.A. (2009a).

Microbial Contamination of Sheep Carcasses at Slaughterhouse in Khartoum State. 
Sud. J. Vet. Sci. Anim. Husb. 48 (1 and 2) $51-56$.

Abdalla, M.A., Suliman, S.E., Ahmed, D.E. and Bakhiet, A.O. (2009b).Estimation of bacterial contamination of indigenous bovine carcasses in Khartoum (Sudan). African Journal of Microbiology Research 3(10) 882-886

Abdalla, M.A., Suliman, SE; Ahmed, D.E. and Bakhiet, A.O. (2010).Methods for Reduction of Contamination of Indigenous Cattle Carcasses during Slaughtering. Assuit Vet. Med. J., 56 (158), 86-93.

Abdelsadig, M.B. (2006). Study of some Critical Control Points in EIKadaro Slaughterhouse. M.Sc. in public health. University of the Academy of Medical Science and Technology. Sudan.

Adetunji VO and Odetokun IA. (2011). Bacterial hazards and critical control points in goat processing at a typical tropical abattoir in Ibadan, Nigeria. Int J Anim Vet Adv., 3: 249-54. Google Scholar

Aftab, M., A. Rahman, M. S. Qureshi, S. Akhter, U. Sadique, A. Sajid and S. Zaman (2012). Level of Salmonella in Beef of Slaughtered Cattle at Peshawar. The Journal of Animal and Plant Sciences, 22(2), 24-27

Ali, A.A., (2007). Prevalence of bacterial contamination of public health concern on bovine carcasses at Khartoum stateSudan. M.Sc. Thesis Sudan University of Science and Technology, Sudan.

Adu-Gyamfi A., W. Torgby-Tetteh and V. Appiah. (2012). Microbiological Quality of Chicken Sold in Accra and Determination of D10-Value of E.coli. Food Nutr. Sci. 3 (5): 693-698.

Bacon, RT., Belk, KE., Sofos, IN., Clayton, RP., Reagan, Ja. and Smith, G.C. (2000). Microbial populations on animal hides and beef carcasses at different stages of slaughter in plants employing multiple-sequential interventions for decontamination. J. Food Prot., 63: 1080-1086.

Bell R. G. (1997). Distribution and sources of microbial contamination on beef carcasses. J Appl Microbiol. 82 (3): 292-300.

Bhandare S. G., A. T. Sherikar, A. M. Paturkar, V. S. Waskar and R. J. Zende. (2007). A comparison of microbial contamination on sheep/goat carcasses in a modern Indian abattoir and traditional meat shops. Food Control. 18 (7): 854-858.

Biss, ME. and Hathaway, S.C. (1995). Microbiological and visible contamination of lamb carcasses according to pres laughter presentation status: Implications for HACCP. J. Food Prot. 58:776-783.

Cernicchiaro, N; Cull, C.A., Paddock, Z.D., Shi, X., Bai, J.P., Nagaraja, T.G.(2013). Prevalence of Shiga toxin-producing Escherichia coli and associated virulence genes in feces of commercial feedlot cattle. Foodborne Pathog Dis; 10: 835-41.

Chen, J. H., Ren, Y., Seow, J., Liu, T., Bang, W. S., and Yuk, H. G. (2012). Intervention Technologies for Ensuring Microbiological Safety of Meat: Current and Future Trends. Comprehensive Reviews in Food Science andFood Safety, 11, 119-132. http://dx.doi.org/10.1111/j.15414337.2011.00177.

Clarence SY, Obinna CN, Shalom NC. (2009). Assessment of bacteriological quality of ready to eat food (Meat pie) in Benin City metropolis, Nigeria. Afr J Microbiol Res; 3: 390-5. Google Scholar

Collobert J, Dorey F, Dieuleveux V, Quillien N. (2002). "Qualitébactériologique de surface de carcasses de bovins". Sciences des aliments, 22/3, 327 - 334 
Dickson, JS and Anderson, M.E. (1991). Control of Salmonella on beef tissue surfaces in a model system by pre and post-evisceration washing and sanitizing, with and without spray chilling. J. Food Prot. 54: 514D518.

Dickson, J.S. and Anderson, M.E. (1992). Microbiological decontamination of food animal carcasses by washing and sanitizing systems: A Review. J. Food Prot. 55: 133D140.

Doyle M. E. (2007).Microbial food spoilage Losses and control strategies, (A brief review of the Literature), FRI Briefings (www.wisc.edu/fri/).

Duffy, G., Cummins, E., Nally, P., O’ Brien, S., and Butler, F. (2006). A review of quantitative microbial risk

assessment in the management of Escherichia coli O157:H7 on beef. Meat Science, 74(1), 76-88.

Elder, R.o., Keen, J.E., Siragusa, G.R.,Barkocy-Galiagher, G.A., Koohmaraie, $\mathrm{M}$ and Laegreid, w.L. (2000). Correlation of enterohemorrhagic Escherichia coli 0157 prevalence in feces, hides and carcasses of beef cattle during processing. Proc. Natl. Acad. Sci. USA 97: 2999-3003.

El-Hadef, El Okki, S., El-Groud, R., Kenana, H., Quessy, S. (2005). Evaluation de la contamination superficielle des carcasses bovines etovinesprovenant de l'abattoir municipal de Constantine en Algérie. Canadian Veterinary Journal, 46, 638-640.

Ercolini D., F. Russo, E. Torrieri, P. Masi and F. Villani.(2006). Changes in the spoilage-related microbiota of beef during refrigerated storage under different packaging conditions. Appl Environ Microbiol. 72 (7): 4663-4671.

European Commission (EU).(2001). Applying microbiological criteria to excised-sample test results. Off J Eur
Comm., 65: 48-56.

Gill, C.O. (1998). Microbiological contamination of meat during slaughter and butchering of cattle, sheep and pigs. In: DA VIES, A., BOARD, R. (Eds.) The Microbiology of Meat and Poultry. London: Blackie Academic and Professional, p. 118-157. [Links]

Gill, CO. and Jones, T. (1999). The microbiological effects of breaking operation on hanging beef carcass sides. Food Res Int., 32: 453-459.

Glimour, A., Murry, K.A. and Madden, R.N, (2004). Determination of the principal points of products contamination during beef 'carcass dressing process in Northern Ireland. J. Food Prot. 67 (7): 1494-6.

Hancock, D.D., Besser, TE. and Rice, D.H. (1998). Ecology of Escherichia coli 0157:H7 in cattle and impact of management practices, p. 85-91. In J.B. Kaper and A.D. O'Brien (ed.), Escherichia coli 0157:H7 and other Shiga toxin producing E. coli strains. ASM Press, Washington, D.C.

Ivanovic S, Pavlovic I, Zujovic M, Tomic Z, Memisi N. (2011).Bacteria in goat meat - biological danger. Biotechnol Anim Husb; 27(3): 1185-92.

Ivanovic S, Baltic ZM, Nesic K, Zujovic M, Ivanovic J, Vukovic S. (2014). Superficial Bacterial Contamination of Goats Carcasses. J Pure Appl Microbiol; 8(1):101-8.

ISO (2002). ISO 6579 - Microbiology of food and animal feeding stuffs - Horizontal method for the detection of Salmonella spp

Geneva, International Organization for Standardization.

Jeffery B, Donald AB, Gill CO.(2003). Implementation of validated HACCP system for the control of microbiological contamination of pig carcass at a small abattoir. 
Käferstein F. K. (2003). Actions to reverse the upward curve of foodborne illness. Food Control. 14 (2): 101-109.

Komba E. V. G., E. V. Komba, E. M. Mkupasi, A. O.Mbyuzi, S. Mshamu, D. Luwumbra, Z. Busagwe and A. Mzula. (2012). Sanitary practices and occurrence of zoonotic conditions in cattle at slaughter in Morogoro Municipality, Tanzania: implications for public health. Tanzania J Health Res. 14 (2): DOI: http://dx.doi.org/10. 4314/thrb.v14i2.6

Li,Q.Z., J.S. Sherwood; C.M. Logue, (2004). The prevalence of Listeria, Salmonella, Escherichia coli and E. coli O157:H7 on bison carcasses during processing Food Microbiology, 21 (6), pp. 791-799

Li M. Y., G. H. Zhou, X. L. Xu, C. B. Li and W. Y. Zhu. (2006). Changes of bacterial diversity and main flora in chilled pork during storage using PCRDGGE. Food Microbiol. 23 (7): 607-611.

Mboto, C.I., Agbo B. E., Ikpoh, I.S., Agbor, R.B., Udoh, D.I., Ambo, E. E. and Ekim, M.A. (2012). Bacteriological study of raw meat of Calabar Abattoir with public health and veterinary importance. J. Microbiol. Biotech. Res., 2(4), $529-532$
Nørrung, B., J. K. Andersen and S. Buncic. (2009). Main Concerns of Pathogenic Microorganisms in Meat Safety of Meat and Processed Meat. F. Toldrá, ed. (Springer New York), pp. 3-29.

Oxoid, LTD. (2006). The oxoid Manual. Ninth. edition. Oxoid, Wade Road, Basingstoke, Hampshire.

Rhoades, J. R., Duffy, G., and Koutsoumanis, K. (2009). Prevalence and concentration of verocytotoxigenic Escherichia coli, Salmonella enterica and Listeria monocytogenes in the beef production chain: a review.

Food Microbiology, 26(4), 357-76. http://dx.doi.org/10.1016/j.fm.2008.10.0 12

Ruby, J. R.J. Zhu, S.C. Ingham (2007). Using indicator bacteria and Salmonella test results from three large-scale beef abattoirs over an 18-month period to evaluate intervention system efficacy and plan carcass testing for Salmonella. Journal of Food Protection, 70 (12), pp. 2732-2740

Quinn, P., Carter, M. M.B and C.G.Carter (2002). Clinical Veterinary Microbiology. Spain: Mosby International Limited; 96-344.

\section{How to cite this article:}

Hamdan Mustafa Hamdan, Mohamed Ismail Mohamed Fangama, Siham Elias Suliman, Ismail Mohamed Fangama and Mohammed Abdel Salam Abdalla. 2019. Microbiological Quality of Goat Carcasses at Different Stages of Slaughter in Dallam Island Abattoir. Int.J.Curr.Microbiol.App.Sci. 8(03): 242-250. doi: https://doi.org/10.20546/ijcmas.2019.803.031 